Western University Scholarship@Western

Centre for the Study of International Economic

Centre for the Study of International Economic

Relations Working Papers

Relations

1986

\title{
Towards a Common Market: Factor Mobility in a Customs Union
}

Ian Wooton

Follow this and additional works at: https://ir.lib.uwo.ca/economicscsier_wp

Part of the Economics Commons

Citation of this paper:

Wooton, Ian. "Towards a Common Market: Factor Mobility in a Customs Union." Centre for the Study of International Economic Relations Working Papers, 8614C. London, ON: Department of Economics, University of Western Ontario (1986). 
$0228-4235$

ISBN

$0-7714-0745-9$

THE CENTRE FOR THE STUDY OF INTERNATIONAL ECONOMIC RELATIONS

WORKING PAPER NO. $8614 \mathrm{C}$

TOWARDS A COMMON MARKET:

FACTOR MOBILITY IN A CUSTOMS UNION

Ian Wooton

This paper contains preliminary findings from research work still in progress and should not be quoted without prior approval of the author.

DEPARTMENT OF ECONOMICS

THE UNIVERSITY OF WESTERN ONTARIO LONDON, CANADA N6A 5C 2
Department of Economics Library

JUL 81986

University of Western Ontario 
TOWARDS A COLYON KARKET:

FACTOR MOBILITY IN A CUSTOAS UNION

Ian Wooton

University of Western Ontario

London

Canada

May 1986

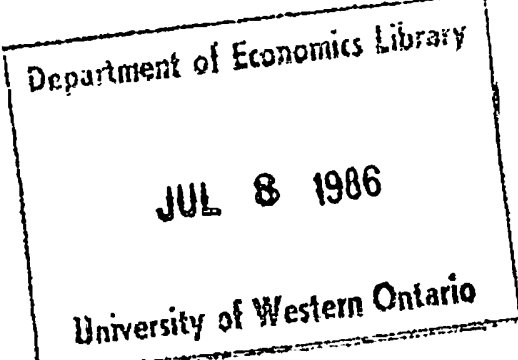




\section{INTRODUCTION}

The theoretical and empirical literature on preferential trading agreements, and in particular on the formation and performance of customs unions, continues to expand. Despite this, there seems to have been no corresponding growth in the analytic discussion of the next stage in economic integration, the common market. Important exceptions are Kemp (1969), Brecher and Bhagwati (1981), and Robson (1984) which complement much of what is done below.

The terminology applied in the literature to the different levels of economic integration has tended to vary. This paper will adopt what seems to be the most conventional usage. A customs union (CU) will be considered to be a coalition of countries that does not charge any taxes on goods traded between themselves but imposes the same structure of taxes on goods traded with the rest of the world, irrespective of which of the member countries produces the goods or finally consumes them. It is this common external tariff (CET) structure that distinguishes the customs union from the free-trade area (FTA), in which each country imposes its own set of taxes on external trade. A common market (CM) is a customs union which also permits the free movement and employment of factors of production.

The general supposition appears to be that factor movements would permit more efficient production within the customs union and hence result in increased welfare for the participating countries [see, for example, Bird (1965)]. What must be recognized, though, is that forming a common market is still, in general, a second-best policy in that the distortion of the CET 
structure remains in place. ${ }^{1}$ Consequently, without further investigation, a ranking of customs unions and common markets is not possible.

The purpose of this paper is to study the welfare effects of permitting factor migration between countries in a customs union--that is, to consider the consequences for the welfare of member countries of moving towards the formation of a common market. Robson (1984) discussed permitting capital flows in a two-factor, two-country model of a customs union. In contrast, Kemp (1969) and Brecher and Bhagwati (1981) considered the effects of trade policies where free factor mobility was already in effect within the union--that is, they considered introducing preferential trading into a free factor market, thereby approaching a common market from a different aspect.

The framework for this analysis will be a variant on the model of preferential trading agreements used by Wooton (1986) and itself based on the approach of Dixit and Norman (1980). The model is very general, incorporating the production of $n$ goods using the services of $m$ factors of production in three countries, where $n$ and $m$ are arbitrary and technology is allowed to differ across the countries. In the next section, below, the general equilibrium of a customs union in a three-country world economy is set out. Following that, in section 3, the general equilibrium effects of factor migration are analyzed. In section 4 , the impact of the factor movements on the welfare of member countries is examined, while section 5 considers the effects on the customs union as a whole. The consequences of induced changes in the terms of trade are discussed in section 6 . The paper concludes with a summary . 


\section{A CUSTOHS UNION}

There are three countries in the world, A, B, and $C$. Each country has $m$ factors of production, all in fixed supply. There are $n$ commodities produced in the world economy and all are consumed in each country. The tastes of consumers in each country are identical and homogeneous, but may differ across countries. Each country trades every good, either importing it from or exporting it to one or both of the other countries. It is assumed that there is no "cross-hauling" of goods, that is, no country can export any good to one country while importing it from the other.

Let the scalar $e^{j}\left(p^{j}, u^{j}\right)$ be the minimum expenditure necessary by country $J$ to achieve utility level $u^{j}$ when the vector of domestic prices of the $n$ goods is $p^{j}$ and let the scalar $r^{j}\left(p^{j}, v^{j}\right)$ be the maximum attainable revenue from production at the same set of domestic prices, given the vector of factors employed in $\mathrm{J}, \mathrm{v}^{\mathbf{j}}$. Consumption demand for goods and the levels of their production are obtained by differentiating with respect to price the expenditure function and the revenue function respectively. Import demand for a particular good is the difference between its domestic demand and domestic supply. Thus the vector of net compensated import demand in country $J$ is

$$
m^{j}=e_{p}^{j}-r_{p}^{j},
$$

where $e_{p}^{j}$ and $r_{p}^{j}$ are, respectively, the vectors of country J's compensated demands for and production of the commodities. Let $t^{j}$ be the vector of specific import tariffs (positive terms) and export taxes (negative terms) imposed by country $J$. The inner product $t^{j} \cdot m^{j}$ is then the total tax revenue generated by country $J$ on its international trade. In equilibrium, each country's expenditure equals the value of its production together with the net revenue from trade taxation. Thus, 


$$
\begin{aligned}
& e^{a}\left(p^{a}, u^{a}\right)=r^{a}\left(p^{a}, v^{a}\right)+t^{a} \cdot m^{a} \\
& e^{b}\left(p^{b}, u^{b}\right)=r^{b}\left(p^{b}, v^{b}\right)+t^{b} \cdot m^{b} \\
& e^{c}\left(p^{c}, u^{c}\right)=r^{c}\left(p^{c}, v^{c}\right)+t^{c} \cdot m^{c}
\end{aligned}
$$

Two of the countries, $A$ and $B$, are members of a customs union. As such, they do not impose any tax impediments on trade with each other. However, any goods that either of the partner countries trades with the rest of the world, country $c$, are subject to taxation, where the vector of taxes is $t^{e}=t^{a}=t^{b}$ : the (specific) tax imposed on trading any particular good is the same for both countries. It is the existence of this set of common external tariffs (CETs) that distinguishes a customs union from a free trade area. The taxes may be positive, zero, or negative depending on the policy objectives of the members of the $\mathrm{CU}$. If the goal is to protect internal industry (that is, operating in the member countries), then the taxes will raise the domestic prices of imported goods relative to the international prices and lower relatively the domestic prices of those goods that are exported to the rest of the world. Tariff revenues are then generated only on external trade (that is, trade with country $c$ ). Let $\mathrm{m}^{\mathrm{ac}}$ and $\mathrm{m}^{\mathrm{bc}}$ be, respectively, the vectors of net imports of countries $A$ and $B$ from country $C$ and thus the inner products $t^{e}$. $m^{a c}$ and $t^{e}$. $m^{b c}$ constitute, respectively, the tariff revenues of $A$ and B. The absence of taxes on intra-union trade results in the domestic prices of $A$ and $B$ being the same, $p^{i}=p^{a}=p^{b}$. The domestic prices faced by consumers and producers in each country deviate from the external international terms of trade, $\mathbf{p}^{\mathbf{e}}$, by the amounts of the specific taxes that are levied by their home government,

$$
p^{e}=p^{i}-t^{e}=p^{c}-t^{c}
$$

The general equilibrium may then be represented $\mathrm{as}^{2}$ : 


$$
\begin{aligned}
& e^{a}\left(p^{i}, u^{a}\right)=r^{a}\left(p^{i}, v^{a}\right)+t^{e} \cdot m^{a c} \\
& e^{b}\left(p^{i}, u^{b}\right)=r^{b}\left(p^{i}, v^{b}\right)+t^{e} \cdot m^{b c} \\
& e^{c}\left(p^{c}, u^{c}\right)=r^{c}\left(p^{c}, v^{c}\right)+t^{c} \cdot m^{c}
\end{aligned}
$$

International excess demand for each good must be zero, and so:

$$
e_{p}^{a}+e_{p}^{b}+e_{p}^{c}-r_{p}^{a}-r_{p}^{b}-r_{p}^{c}=0 ;
$$

that is,

$$
\mathrm{m}^{\mathrm{a}}+\mathrm{m}^{\mathrm{b}}+\mathrm{m}^{\mathrm{c}}=0
$$

\section{FACTOR MIGRATION}

The members of the customs union now decide to permit movement of

factors from one country to the other. The factors will then be employed in their country of immigration, but their consumption will be considered to remain part of their home country's welfare. ${ }^{3}$ Countries are considered able to control both the inflow and outflow of both numbers and types of factors, but cannot discriminate against immigrants in terms of factor payments--all factors, irrespective of national origin, are paid their marginal products.

Let the vectors of factor endowments of countries $A$ and $B$ be $v^{-a}$ and $v^{-b}$, respectively. The sum of these stocks constitutes the factor pool of the customs union. With full employment of all factors,

$$
\mathbf{v}^{\mathbf{a}}+\mathbf{v}^{\mathbf{b}}=\mathbf{v}^{-\mathbf{a}}+\mathbf{v}^{-\mathbf{b}}
$$

Let $v^{*}$ be the vector of factor immigration into country A. Thus positive terms of the vector will indicate migration of that factor from $B$ to $A$, whereas negative terms will indicate a migration from $A$ to $B$. Employment in the two member countries is: 


$$
\begin{aligned}
& v^{a}=\bar{v}^{\mathbf{a}}+\mathbf{v}^{*} \\
& v^{b}=\bar{v}^{-b}-v^{*}
\end{aligned}
$$

All migration is voluntary and so factors will only move when the payment for their services is greater in the other country than it is in the country in which they are currently working. Letting $w^{a}$ and $w^{b}$ represent the vectors of factor payments in the respective countries and defining ${ }^{*}$ to be the vector of payments to migrant factors, then

$$
w^{*}=\max \left[w^{a}, w^{b}\right]
$$

The income-expenditure equations of countries $A$ and $B$ now must incorporate the transfers of migrant income:

$$
\begin{aligned}
& e^{a}\left(p^{i}, u^{a}\right)=r^{a}\left(p^{i}, v^{a}\right)+t^{e} \cdot m^{a c}-w^{*} \cdot v^{*} \\
& e^{b}\left(p^{i}, u^{b}\right)=r^{b}\left(p^{i}, v^{b}\right)+t^{e} \cdot m^{b c}+w^{*} \cdot v^{*}
\end{aligned}
$$

Equations (4), (5), (8), and (9) constitute the full general equilibrium of a customs union with factor mobility, and would correspond to a common market if additionally,

$$
w^{*}=w^{a}=w^{b}
$$

Consider the effects of permitting additional migration between the partner countries. Trade taxes are not changed and therefore any induced changes in prices will be common to all of the countries. That is, the changes in the terms of trade of the countries are:

$$
d p=d p^{a}=d p^{b}=d p^{i}=d p^{e}=d p^{c}
$$


Taking total differentials of equations (8), (9), and (4) and substituting in (10) yields

$$
\begin{aligned}
& e_{p}^{a} \cdot d p+e_{u}^{a} d u^{a}=r_{p}^{a} \cdot d p+r_{v}^{a} \cdot d v^{*}+t^{e} \cdot d m{ }^{a c}-w^{*} \cdot d v^{*}-v^{*} \cdot d w^{*} \\
& e_{p}^{b} \cdot d p+e_{u}^{b} d u^{b}=r_{p}^{b} \cdot d p-r_{v}^{b} \cdot d v^{*}+t^{e} \cdot d m b c+w^{*} \cdot d v^{*}+v^{*} \cdot d w^{*} \\
& e_{p}^{c} \cdot d p+e_{u}^{c} d u^{c}=r_{p}^{c} \cdot d p+t^{c} \cdot d m^{c}
\end{aligned}
$$

Now $r_{v}^{j}$ is the vector of marginal products of factors employed in country $J$ and thus equals $w^{j}$. Using this and equation (1) to simplify the above expressions yields:

$$
\begin{aligned}
& e_{u^{a} d u^{a}}^{e^{2}}=\left(w^{a}-w^{*}\right) \cdot d v^{*}-v^{*} \cdot d w^{*}+t^{e} \cdot d m^{a c}-m^{a} \cdot d p \\
& e_{u^{b}}^{d} u^{b}=\left(w^{*}-w^{b}\right) \cdot d v^{*}+v^{*} \cdot d w^{*}+t^{e} \cdot d m^{b c}-m^{b} \cdot d p \\
& e_{u^{c} d u^{c}}=t^{c} \cdot d m^{c}-m^{c} \cdot d p
\end{aligned}
$$

The welfare impact for the world as a whole from the change in factor migration can be obtained by summing across (11), (12), and (13):

$$
e_{u}^{a} d u^{a}+e_{u}^{b} d u^{b}+e_{u^{c}}^{c} u^{c}=\left(w^{a}-w^{b}\right) \cdot d v^{*}+\left(t^{e}-t^{c}\right) \cdot d m^{e}
$$

where $d m^{e}=\left(d m^{a c}+d m^{b c}\right)=-d m^{c}$. The terms-of-trade terms net out to zero, as do the intra-union transfers of factor payments. The factor movements affect world welfare in two ways: through their impact on efficient allocation; and through their induced effects on the volume of world trade. World welfare will increase as a direct result of the migration if factors move from low-paying to high-paying countries--.the first term will be positive if $w_{k}^{a}<w_{k}^{b}$ then $d v_{k}^{*}>0$, for any factor $k$. 
Were there no taxes on trade, then this would be the end of the story from the world's perspective. However there are tariffs on trade between the $\mathrm{CU}$ and the rest of the world, and the factor migration may induce changes in the volume of trade, changing tariff revenues. This welfare effect will be positive if the volume of trade rises. If good $X$ is imported by the $\mathrm{CU}$ and exported by $c$, then $t_{x}^{e}>0$ and $t_{x}^{c}<0$. These inequalities would be reversed were $X$ an export of the $C U$. The difference between the two taxes is the total absolute revenue collected on the trade of one unit of the good, where

$$
\left(t_{x}^{e}-t_{x}^{c}\right) \geqslant 0 \text { for } m_{x}^{e} \geqslant 0
$$

If trade increases, i.e. $\mathrm{dm}_{x}^{e} \gtrless 0$ for $m_{x}^{e} \gtrless 0$, then the volume of trade effect increases world welfare. In Wooton's (1986) discussion of preferential trading agreements, world welfare is affected only through changes in the volume of trade (as, in that analysis, factors are completely immobile between countries).

The remainder of this paper will determine the conditions under which the liberalization of controls on factor mobility will be welfare-improving for the members of the $\mathrm{CU}$.

\section{WELFARE OF MEMBER COUNTRIES}

Consider the impact on the welfare of countries $A$ and $B$ of a change in the quantity of migrant factors. Equations (11) and (12) each have four terms influencing the welfare of $A$ and $B$, respectively. Now take each of the terms in turn (starting with the extreme left-hand term and working to the right) and determine its contribution to the change in welfare. 


\subsection{Factor allocative efficiency}

It was determined that for the $\mathrm{CU}$ as a whole (and, indeed, for the world) the factor movements yielded efficiency gains. It turns out that these gains accrue to the country of emigration, with the host country being made no better or worse off. To see this, remember that factors will only be willing to move if the reward offered for their services is higher in the other country. If factor $\mathrm{K}$ is initially employed in country $\mathrm{B}$, it will be willing to move only if the $w_{k}^{*}$ that it could earn through emigration exceeds its current earnings of $w_{k}^{b}$, the marginal productivity of $k$ in production in country B. As its prospective employer is country A, the payment for factor services there is the marginal product in $A$ and so $w_{k}^{*}=w_{k}^{a}$. Thus for $d v_{k}^{*}>0$, country $A^{\prime}$ 's production expands by the marginal productivity of factor $K$, but this is exactly offset by the payment that $A$ must make to the factor. In country $B$, the emigration of $K$ reduces output by $w_{k}^{b}$, but this is more than compensated by the remittances from $K$ now employed in $A$. $A$ general result for the first terms on the right-hand-sides of equations (11) and (12) can then be determined:

$$
\begin{aligned}
& \left(w_{k}^{a}-w_{k}^{*}\right)=0<\left(w_{k}^{*}-w_{k}^{b}\right) \quad \Leftrightarrow \quad d_{k}^{*}>0 \\
& \left(w_{k}^{a}-w_{k}^{*}\right)<0=\left(w_{k}^{*}-w_{k}^{b}\right) \Leftrightarrow d v_{k}^{*}<0
\end{aligned}
$$

Thus the inner products are the sums of positive and zero terms, and so the efficient allocation of factors within the customs union can only benefit each of the member countries.

\subsection{Factor remittances}

For the CU as a whole, the transfer of factor earnings from the host country to the factors' home countries has no effect--the loss of national income in $A$ is exactly compensated by the gain in B's national income and 
vice versa. Of course, these flows are important for the individual member countries, as will be any changes in these remittances induced by further factor migration. Were the CU only beginning to permit very limited migration, then $v^{*}=0$, and this term would also be zero.

Consider how migrant earnings are affected when the volume of migration changes. Totally differentiating the vectors of factor payments in the two countries:

$$
\begin{aligned}
& d w^{a}=d r_{v}^{a}=r_{v p}^{a} d p+r_{v v}^{a} v^{*} \\
& d w^{b}=d r_{v}^{b}=r_{v p}^{b} d p-r_{v v}^{b} d v^{\star}
\end{aligned}
$$

Now,

$$
d w_{k}^{*}=d w_{k}^{a} \text { if } v_{k}^{*}>0 \text { and } d w_{k}^{*}=d w_{k}^{b} \text {, if } v_{k}^{*}<0 \text {. }
$$

The returns to each factor are affected in two fashions. Firstly, there is the direct impact that the increased (or decreased) employment of migrant factors will have on the marginal products of those factors already in employment. 4 Earlier migrants will benefit from increased employment of complementary factors, but will lose if more of their own type of factor, or of any other substitute factor, are hired. Similarly, factors will benefit from an exodus of substitute factors but will lose if complementary factors move to the other country. Clearly countries have monopoly/monopsony power in the factor markets in that they can affect the payments to migrants by restricting immigration or emigration. While the first welfare term shows that increased liberalization of migration necessarily generates benefits for the customs union, these benefits may be reduced, or even reversed, for an individual country by a fall in overall migrant factor revenues. In the latter circumstance, where it is in the interests of such a country to limit 
migration, its partner would benefit from bribing it to allow freer movements--in the same way as it is in the interests of one country to bribe another not to impose trade tariffs. 5

The second effect is the terms-of-trade effect: the factor migration changes international prices and, by a high-dimensional analogue of the Stolper-Samuelson effect, will change the returns to the factors of production. Which factors will gain from the changes in relative prices, and which will lose, depends both on what the price changes are and on the Stolper-Samuelson-type relationships between goods and factors. ${ }^{6}$ To determine the impact of the change in the terms of trade on migrant incomes would then require specific knowledge of the production functions.

\subsection{Volume of trade effects}

The effect of changes in the volume of trade on the tariff revenues collected in the $\mathrm{CU}$ as a whole is

$$
t^{e} \cdot d m^{e}=t^{e} \cdot d m^{a c}+t^{e} \cdot d m^{b c}
$$

Now $d m^{a}+d m^{b}=d m^{a c}+d m^{b c}$, because $d m^{a b}=-d m^{b a}$ (the exports of

one member are the imports of its partner). Thus $\mathrm{dm}^{e}=\mathrm{dm}^{a}+\mathrm{dm}^{\mathrm{b}}$, the change in net imports of the $\mathrm{CU}$ is the sum of the two partner countries' changes in net import demand. Determine now what influences the volume of trade undertaken by countries. Totally differentiating the vectors of net compensated import demands for $A$ and $B$ :

$$
\begin{aligned}
d m^{a} & =e_{p p}^{a} d p+e_{p u}^{a} d u^{a}-r_{p p}^{a} d p-r_{p v}^{a} d v^{*} \\
d m^{b} & =e_{p p}^{b} d p+e_{p u}^{b} d u^{b}-r_{p p}^{b} d p+r_{p v}^{b} d v^{*}
\end{aligned}
$$


Net import demand varies as a result of both consumption and production changes. Consumption demand is affected by changes in welfare and in relative prices while production shifts are due to changes both in factor supplies and in relative prices. Let $s^{j}=e_{p p}^{j}-r_{p p}^{j}$, (for $j=a, b$, and c) the matrix of derivatives of a country's excess demands for goods with respect to prices. Also, let $e_{p}^{j}=c_{p}^{j}$, the domestic demand vector of country J. Then:

$$
\underset{p u}{j}=\underset{c_{u}}{j}=c_{y}^{j} \underset{y_{u}}{j}=c_{y}^{j} e_{u}^{j}
$$

where $y$ is defined as money income. Substituting these definitions into equations (15) and (16) yields,

$$
\begin{aligned}
& d m^{a}=c_{y}^{a} e_{u}^{a} d u^{a}-r_{p v}^{a} d v^{*}+s^{a} d p \\
& d m^{b}=c_{y}^{b} e_{u}^{b} d u^{b}+r_{p v}^{b} d v^{*}+s^{b} d p
\end{aligned}
$$

Therefore:

$t^{e} \cdot d m^{e}=t^{e} \cdot\left(c_{y}^{a} e^{a} d u^{a}+c_{y}^{b} e^{b} d u^{b}\right)+t^{e^{\prime}}\left(r_{p v}^{b}-r_{p v}^{a}\right) d v^{*}+t^{e^{\prime}}\left(s^{a}+s^{b}\right) d p$

where $t^{e^{\prime}}$ is the transpose of the vector of common external tariffs. If the welfare of the CU rises, demands for all goods increase (assuming normality). Tax revenues rise for goods that are imported by the $\mathrm{CU}$, but export revenues fall as goods are diverted from (revenue-earning) export to intra-union consumption. Intra-union production of goods may change as factors are reallocated between countries and so, even with unchanged demand, tariff revenues may change. The last term captures the change in tax revenues resulting from shifts in consumption and production in response to changes in prices. 
Equation (17) determines the magnitude of gains realized by the CU as a whole, but gives no clue as to how these gains are distributed between the partner countries. The actual gains made by each of the partners from a change in the volume of trade depend, not upon the changes in net imports, but upon the changes in the quantities of these goods that are traded with the rest of the world. Tariffs and taxes are only collected on goods which are imported to or exported from $C$, as trade with a partner is free of taxation. It is the country that trades with the rest of the world that captures any tariff revenues. The welfare impact for each partner is $t^{e} \cdot \mathrm{dm}^{j c}$, not $t^{e} \cdot \mathrm{dm}^{j}$. Hence, in order to determine how a country's tax receipts will change, and thereby determine its share of the gains or losses from the volume of trade effect, the pattern in which each good is traded must be known.

Partition the set of $\mathrm{n}$ goods into three, corresponding to the three possible patterns of trading: $A-B-C, B-A-C, A-C-B$, where the middle country of the three either exports the good to both of the other countries or imports it from both (there being no cross-hauling of any good). If the set of common external tariffs is designed to protect import-competing industries in the $\mathrm{CU}$, then the CET will be composed of import tariffs and export taxes and an increase in the inflow of imported goods or an increase in the sales to $C$ of export goods will generate increased tax revenues.

Consider first of all the goods traded according to pattern A-C-B. Good $X$ in this subset is either imported by both $A$ and $B$ or exported by both. In this case there can be no trade between $A$ and $B$, and thus: $\mathrm{dm}_{x}^{a}=\mathrm{dm}_{x}^{a c}$ and $\mathrm{dm}_{\mathrm{x}}^{\mathrm{b}}=\mathrm{dm}_{\mathrm{x}}^{\mathrm{bc}}$. Every good traded by the customs union is traded with the rest of the world and is therefore subject to tax. The tax revenues accrue to each partner country according to its own trade in the good. 
For either of the other two trade patterns only one of the partner countries trades with $C$. Consider pattern A-B-C. Country A's trade is exclusively with its partner and so the trade is untaxed. Any change in the volume of its trade will therefore have no effect on $A$ 's tariff revenues and so no impact on the country's welfare. Part of B's trade must also then be untaxed--that part which is conducted with A--but the remainder is subject to the CET. When the volume of trade in these goods changes, in response to the factor movements, the gains (or losses) are captured entirely by country B. In an exactly parallel fashion, country $A$ is the sole partner affected by changes in the volume of trade of goods in the pattern B-A-C. Sumarizing the tariff effects:

Trade

Pattern

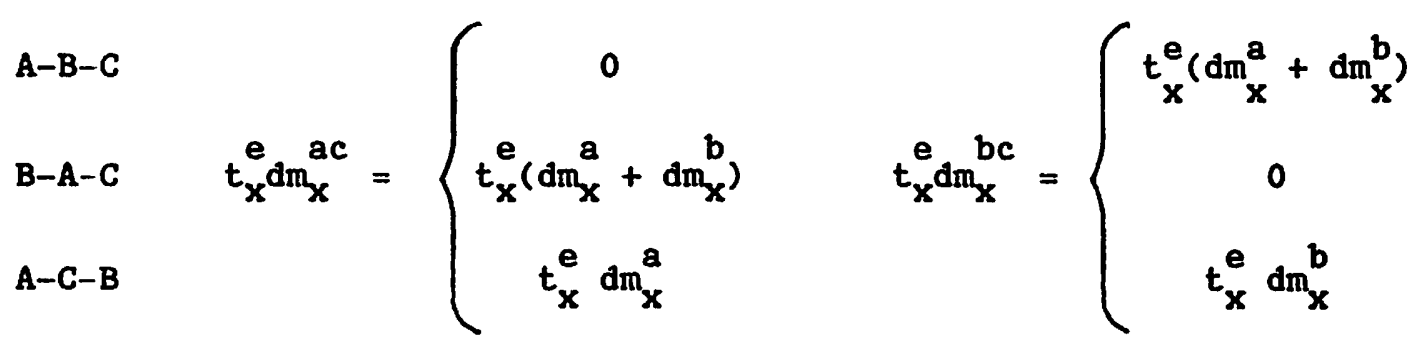

\subsection{Terms of trade effects}

Changes in the terms of trade influence the welfare of the members of the customs union in several ways. Firstly there is the direct effect of changes in the world trading prices on the cost of imports relative to exports, the fourth term of equations (11) and (12). These changes will benefit those countries whose export prices rise relatively to the prices of their imports. Terms of trade gains may fall upon one, both, or neither of the member countries in the CU depending on the structure of production and consumption in the world. 
These same adjustments in prices have also been shown to work through some of the other terms in equations (11) and (12). Specifically, the price changes, by altering the patterns of consumption and production could affect the levels of tariff revenues collected by the member countries. Also, the change in prices will work through the Stolper-Samuelson analogue to change factor rewards and thereby affect the level of migrant factor remittances.

\section{WELFARE OF THE CUSTOHS UNION}

So far it has been shown that both countries individually gain from efficient intra-union reallocation of individual factors, but that this migration might cause a fall in a member country's remitted earnings from emigrant workers. The distribution of gains or losses from changes in the volume of trade is not related to the quantity of trade undertaken by individual countries, but rather to the volume of trade they conduct with the rest of the world. Terms of trade changes may be to the advantage of both, one, or neither member of the customs union.

The lack of knowledge about countries' volumes of trade with $\mathrm{C}$ makes it impossible to make statements about gains from factor mobility for specific countries. However the size of the volume of trade effect is known for the CU as a whole and conditions for overall gains being made by the $\mathrm{CU}$ might be made, with an assumption that these gains are (if necessary) redistributed between the partners to make the move towards a common market to be Pareto-improving.

of course, given that customs unions and common markets are both second-best situations, it is not immediately clear that either country will gain. Adding together equations (11) and (12) to find the welfare of the CU 
as a whole:

$$
e_{u}^{a} d u^{a}+e_{u}^{a} d u^{a}=\left(w^{a}-w^{b}\right) \cdot d v^{*}+t^{e} \cdot d m{ }^{e}-m^{e} \cdot d p
$$

The first term on the right-hand side is positive, being the gains from the efficient reallocation of factors in the customs union. The actual distribution of these benefits between the countries was determined above. Any change in the flow of remitted factor payments benefits one country at the expense of the other and so the intra-union transfer terms cancel out for the CU. It would be possible for the country that has benefitted to compensate its partner for its losses, while both enjoy the benefits of the efficiency gains. If the members of the CU are "small" (and the CU as a whole is also "smal1") then the factor movements will have no effect on prices, that is, $d p=0$. In such a situation, the optimal CET is known to be zero. With zero trade taxes, the welfare of the CU must rise when factors are permitted to move and, if the transferred earnings are appropriately redistributed, both countries will gain. of course, this is just the result that, if factor prices are not equalized by free trade, factor mobility is complementary to trade in goods and yields benefits of higher production. For a discussion of this see Markusen (1983).

Continue to consider the $\mathrm{CU}$ as "small", but suppose that the vector of common external tariffs is non-zero (and thereby non-optimal). Hence a move to free factor mobility will be a shift from one second-best regime to another. Substituting $d p=0$ and equation (17) into equation (18) and rearranging yields: 


$$
\left(1-t^{e} \cdot c_{y}^{a}\right) e_{u}^{a} d u^{a}+\left(1-t^{e} \cdot c^{b}\right) e_{y}^{b} d u_{u}^{b}=\left(w^{a}-w^{b}\right) \cdot d v^{*}+t^{e}\left(r_{p v}^{b}-r_{p v}^{a}\right) d v^{*}
$$

Given $t^{e} \cdot c_{y}^{j}<1$, for $j=a, b$, then the welfare of the cU rises if the right-hand side of equation (19) is positive. It has already been determined that the first term, the change in allocative efficiency is greater than zero. The second term quantifies the interaction between the two distortions, measuring the effect of the factor movements on the trade-tax revenues. $r_{p v}^{j} d^{*}$ is a vector of the change in country $J^{\prime} s$ production of the $n$ goods (at constant commodity prices) resulting from a change in factor supplies. $\left(r_{p v}^{b}-r_{p v}^{a}\right) d v^{*}$ is therefore the net change in production in the CU resulting from the factor migration. At constant prices, consumption demand is unchanging and any increased commodity production will be exported to $\mathrm{C}$ and any reduction in the production of a good must be compensated by an increase in its import. If the factor reallocation leads to rising production of export goods and to reduced production of imported goods the tax and tariff revenues generated by trade with the rest of the world will rise. If this is the case, the second term will increase the general welfare of the CU.

The intuition behind this is quite straightforward. The CU does not have any monopoly power in trade and hence the trade taxes reduce welfare by promoting intra-union production of (what should be) import goods and by discouraging the production of export goods. If the factor reallocation pushes production in the opposite direction then, in addition to the efficiency gains, it also helps to offset the impact of the tax distortion, moving intra-union production towards its free-trade levels, and so welfare is unambiguously improved. If, however, the migration reinforces the tariff (by 
leading to even more import-competing production) then it is possible that the move towards a common market is worse (in terms of welfare) than the customs union.

\section{A "LARGE" CUSTOHS UNION}

Suppose now that the customs union is "large", in that, by its actions, it can alter the prices of goods produced and consumed in the world economy. The generality of the model now, in large degree, works against it as little can be determined without the full specification of the structure of production and consumption. Solve first for the change in international prices as a result of the factor migration. Totally differentiate equation (5), letting $s=s^{a}+s^{b}+s^{c}$ :

$$
c_{y}^{a} e_{u}^{a} d u^{a}+c_{y}^{b} e_{u}^{b} d u^{b}+c_{y}^{c} e_{u}^{c} d u^{c}=-s d p+\left(r_{p v}^{a}-r_{p v}^{b}\right) d v^{*}
$$

Also, define $s^{e}=s^{a}+s^{b}$, the substitution matrix for the entire $c u$.

Given that the distribution between member countries of the gains from changes in the volume of trade is unknown, the best that done in analyzing the "large-countries" effects is the determination of the welfare effects for the customs union as a whole. In order to permit some degree of tractability, even this needs an additional assumption about tastes: assume that the consumption of each good from a marginal dollar's income for both countries in the $\mathrm{CU}$ is the same; that is,

$$
c_{y}^{a}=c_{y}^{b}=c_{y}^{e}
$$

Note also that,

$$
\mathrm{dm}^{c}=s^{c}+c_{y}^{c} e^{c} d u^{c}
$$


Substituting equations (20), (21), and (22) into (13) and (19) and solving:

$\left[\begin{array}{ll}A^{e} & B^{e} \\ B^{c} & A^{c}\end{array}\right]\left[\begin{array}{c}e_{u^{a} d u^{a}}^{a}+e_{u}^{a} d u \\ e_{u}^{c} d u^{c}\end{array}\right]=\left[\begin{array}{c}\left(w^{a^{\prime}}-w^{b}\right)+\left(t^{e^{\prime}}+B^{e}\right)\left(r_{p v}^{a}-r_{p v}^{b}\right) \\ B^{c}\left(r_{p v}^{a}-r_{p v}^{b}\right)\end{array}\right] d v^{*}$

where $B^{j}=\left(t^{j^{\prime}} s^{j}-m^{j}\right) s^{-1} c_{y}^{j}$ and $A^{j}=\left(1-t^{j} \cdot c_{y}^{j}\right)+B^{j}$, for $j=c, e$.

No attempt is made here to solve this system of equations. However some insight into the effects of the factor migration can be elicited. Firstly, the "smal1-countries" effects on members of the CU, from allocative efficiency and volume of trade changes, remain. In addition, both the $\mathrm{CU}$ and country $\mathrm{C}$ are exposed to terms of trade changes. These are partly generated by the CU's changes in demand resulting from the "smal1-countries" effects. Apart from these, the factor migration also changes the production mix in the customs union. At constant commodity prices, this would generate excess demand for some goods and excess supply of others in the world economy as a whole. The consequent terms of trade changes may benefit or harm $C$ and may reduce or augment any other gains made by the CU from its liberalization of factor movements. 8

\section{SUMMARY AND CONCLUSIONS}

The analysis of customs unions and common markets is the analysis of second-best situations and, as such, is an important part of the vast literature on international trade and distortions. The move towards a common market involves the removal of one distortion (factor immobility) while leaving another, the CET, in place. If the CU is large, then the second distortion is not the CET itself but a non-optimal set of trade taxes.

It has been shown in the paper that each member country of the CU is able to capture some of the efficiency gains from the international reallocation of the factors of production and that the partners can 
compensate one another for changes in the volume of remittances made by migrant factors to their home countries. Thus, as free trade is optimal for the world as a whole when there are no other distrtions present, then so too is free factor mobility optimal.

For a "small" customs union, moving towards a common market was shown to be unambiguously welfare-improving when the migration mitigated the distortion induced by the trade taxes. This was because production was pushed back towards free-trade levels, with higher output of export goods and lower output of import-competing commodities.

Changes in international prices, resulting from the intra-union factor mobility, could result in an expansion or a reduction in the gains to the partner countries. Which eventuality would occur would depend on the structure of tastes, technology, and factor endowments in the world. 
FOOTWOTES

*I would like to thank Jim Melvin and Peter Robson for help and comments. This research was supported by the Social Sciences and Humanities Research Council of Canada.

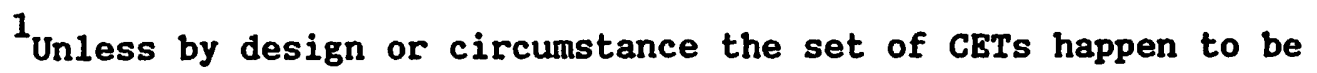
"optimal".

2 Wooton [1986] determined that transfers may have to be made between countries to compensate some of them for their loss of tariff revenues resulting from the formation of the customs union. These could be incorporated into the the income-expenditure equations as constant scalars, without changing the results. Consequently they are ignored.

${ }^{3}$ It is also assumed by this that factors do not adopt the demand patterns of the country in which they work. One way of thinking about this is that all factor payments are fully remitted to the home country, where they are spent on consumption.

${ }^{4}$ of course, it may be that factor migration has no effect on factor rewards--as is the case of the Rybczynski effect in the $2 \times 2$ model and (under certain circumstances) in higher dimensional models (see Ethier (1984) on this].

${ }^{5}$ There is a large literature on optimal factor movements, starting with the classic Ramaswami (1968) article. For further references, see Kuhn and Wooton (1986).

${ }^{6}$ See Ethier (1984) for a discussion of the stolper-Samuelson relations in high dimensional trade models.

This, of course, means that the tastes of the two member countries are the same--which is not assumed elsewhere in the paper.

${ }^{8}$ If the CU has been setting "optimal" tariffs, then these are likely to change as a result of the factor movements. 


\section{REFERENCES}

Brecher, Richard A. and Jagdish N. Bhagwati (1981), "Foreign ownership and the theory of trade and welfare", Journal of Political Economy 89: 497-511.

Bird, R. (1965), "The need for regional policy in a common market", Scottish Journal of Political Economy 12: 225-42. Reprinted in Peter Robson (editor), International Economic Integration (Penguin, Harmondsworth).

Dixit, Avinash and Victor Norman (1980), Theory of International Trade (James Nisbet and Company, Welwyn).

Ethier, Wilfred J. (1984), "Higher dimensional issues in trade theory", in Ronald W. Jones and Peter B. Kenen (editors), Handbook of International Economics (North Holland, Amsterdam).

Kemp, Murray C. (1969), A contribution to the general equilibrium theory of preferential trading (North-Holland, Amsterdam).

Kuhn, Peter and Ian Wooton (1986), "International factor movements in the presence of a fixed factor", Journal of International Economics, forthcoming.

Markusen, James R. (1983), "Factor movements and commodity trade as complements", Journal of International Economics 14: 341-356.

Ramaswami, V.K. (1968), "International factor movement and the national advantage", Economica 35: 309-310.

Robson, Peter (1984), The Economics of International Integration, second edition (George Allen \& Unwin, London).

Wooton, Ian (1986), "Preferential trading agreements: an investigation", Journal of International Economics, forthcoming. 
$8401 \mathrm{C}$ Harrison, Glenn $w$. and Manning, Rlchard. BEST APPROXIMATE AGGREATION OF INPUT-OUTPUT SYSTEMS.

8402C Parkin, Michael. CORE INFLATION: A REVIEW ESSAY.

8403C Blomqvist, Ảke, and McMahon, Gary. SIMULATING COMMERICAI POLICY IN A SMALL, OPEN DUAL ECONOMY WITH URBAN UNEMPLOYMENT: A GENERAL EQUILIBRIUM APPROACH.

8404C Wonnacott, Ronald. THE THEORY OF TRADE DISCRIMINATION: THE MIRROR IMAGE OF VINERIAN PREFERENCE THEORY?

8405C Whalley, John. IMPACTS OF A 50\% TARIFF REDUCTION IN AN EIGHT-REGION GLOBAL TRADE MODEL.

8406C Haryison, Glenn W. A GENERAL EQUILIBRIUM ANALYSIS OF TARIFP REDUCTIONS.

8407C Horstmann, Ignatius and Markusen, James R. STRATEGIC INVESTMENTS AND THE DEVELOPMENT OF MULTINATIONALS.

8408C Gregory, Allan W. and McCurdy, Thomas H. TESTING THE UNBIASEDNESS HYPOTHESIS IN THE FORINARD FOREIGN EXCHANGE MARKET: A SPECIFICATION ANALYSIS.

8409C Jones, Ronald H. and Klerzkowsk1, Henryk. NEIGHBORHOOD PRODUCTION STRUCTURES WITH APPLICATIONS TO THE THEORY OF INTERNATIONAL TRADE.

$8410 \mathrm{C}$ Weller, Paul and Yano, Makoto. THE ROLE OF FUTURES MARKETS IN INTERNATIONAL TRADE: A GENERAL EỌUILIBRIUM APPROACH.

$8411 \mathrm{C}$ Brecher, Richard $\mathrm{A}$. and Bhagwat1, Jagdish $\mathrm{N}$. VOLUNTARY EXPORT RESTRICTIONS VERSUS IMPORT RESTRICTIONS: A WELFARE-THEORETIC COMPARISON.

8412C Ethier, W11fred J. ILLEGAL IMMIGRATION.

8413C Eaton, Jonathon and Gene M. Grossman. OPTIMAL TRADE AND INDUSTRIAL POLICY UNDER OLIGOPOLY.

8414C Wooton, Ian. PREFERENTIAL TRADING AGREEMENTS - A 3xn MODEL.

8415C Parkin, Michael. DISCRIMINATJN, BETWEEN KEYNESIAN AND CLASSICAL TUEORIES OF THE BUSINESS CYCLE \& JAPAN 1967-1282

8416C Deardorff, Alan V. FIRless FIRwoes: HOW PREFERENCES CAN INTERFERE WITH THE THEOREMS OF INTERNATIONAL TRADE.

8417C Greenwood, Jeremy. NONTRADED GOODS, THE TRADE BALANCE, AND THE BALANCE OF PAYNENTS. 
$8418 \mathrm{C}$ Blomqvist, Ake and Sharif Mohammad. CONTROLS; CORRUPTION, AND COMPETITIVE RENT-SEEKINF IN LDCs.

8419C Grossman, Herschel I. POLICY, RATIONAL EXPECTATIONS, AND POSITIVE ECONOMIC ANALYSIS.

8420C Garber, Peter M. and Robert G. King. DEEP STRUCTURAL EXCAVATION? A CRITIOUUE OF EULER EQUATION METHODS.

8421C Barro, Robert J. THE BEHAVIOR OF U.S. DEFICITS.

8422C Persson, Torsten and Lars E.0. Svensson. INTERNATIONAL BORROWING AND TIME-CONSISTENT FISCAL POLICY.

8423C. Obstfeld Maurice. CAPITAL CONTROLS, THE DUAL EXCHANGE RATE, AND DEVALUATION.

8424C Kuhn, Peter. UNION PRODUCTIVITY EFFECTS AND ECONOMIC EFFICIENCY.

8425C Hamilton, Bob and John Whalley. TAX TREATMENT OF HOUSING IN A DYNAMIC SEOQUENCED GENERAL EỌUILIBRIUM MODEL.

$\because 426 \mathrm{C}$ Hamilton, Bob, Shartf Mohammad, and John Whalley, RENT SEEKING AND THE NORTH-SOUTH TERMS OF TRADE.

8427C Adams, Charles and Jeremy Greenwood. DUAL EXCHANGE RATE SYSTEMS AND CAPITAL CONTROLS: AN INVESTIGATION.

8428 Loh, Choon Cheong and Michael R. Veall. A NOTE ON SOCIAL SECURITY AND PRIVATE SAVINGS IN SINGAPORE.

8429 Whalley, John. REGRESSION OR PROGRESSION: THE TAYING OUUESTION OF INCIDENCE ANALYSIS.

3430 Kuhn, Peter. WAGES, EFFORT, AND INCENTIVE-COMPATIBILITY IN LIFE-CYCLE EMPLOYMENT CONTRACTS.

8431 Greenwood, Jeremy and Kent P. KImbrough. AN INVESTIGATION IN THE THEORY OF FOREIGN EXCHANGE CONTROLS.

8432 Greenwood, Jeremy and Kent P. KImbrough. CAPITAL CONTROLS AND THE INTERNATIONAL TRANSMISSION OF FISCAL POLICY.

8433 : Nguyen, Trien Trien and John Whalley. EỌIILIBRIUM UNDER PRICE CONTROLS WITH ENDOGENOUS TRANSACTIONS COSTS.

8434 Adams, Charles and Russell S. Boyer. EFFICIENCY AND A SIMPLE MODEL OF EXCHANGE RATE DETERMINATION. 
8435 Kuhn, Peter. UNIONS, ENTREPRENEURSHIP, AND EFFICIENCY.

8436 Hercowttz, Zv1 and Efraim Sadka. ON OPTIMAL CURRENCY. SUBSTITUTION POLICY AND PUBLIC PINANCE.

8437 Lenfosek, Gordon and John Whalley, POLICY EVALUATION IN A SMALL OPEN PRICE TAKING ECONOMY: CANADIAN ENERGY POLICIES.

8438 Aschauer, David and Jeremy Greenwood. MACROECONOMIC EFFECTS OF FISCAI POLICY.

8439C Hercowitz, Zv1. ON THE DETERMINATION OF THE EXTERNAL DEBT: THE CASE OF ISRAEL.

8440C Stern, Robert M. GLOBAL DIMENSIONS AND DETERMINANTS OF INTERNATIONAL TRADE AND INVESTMENT IN SERVICES.

8441C Deardorff, Alan V. COMPARATIVE ADVANTAGE AND INTERNATIONAL TRADE AND INVESTMENT IN SERVICES.

8442C Daly, Donald J. TECHNOLOGY TRANSFER AND CANADA'S COMPETITIVE PERFORMANCE.

8443C Grey, Rodney de C. NEGOTIATING ABOUT TRADE AND INVESTMENT IN SERVICES.

8444C Grossman, Gene $M$. and Carl Shapiro. NORMATIVE ISSUES RAISED BY INTERNATIONAL TRADE IN TECHNOLOGY SERVICES.

3445C Chant, John F. THE CANADIAN TREATMENT OF FOREIGN BANKS: A CASE STUDY IN THE WORKINGS OF THE NATIONAL TREATMENT APPROACH.

8446C Aronson, Jonathan D. and Peter F. Cowhey. COMPUTER, DATA PROCESSING, AND COMMUNICATION SERVICES.

8447C Feketrkuty, Geza.- NEGOTIATING STRATEGIES FOR LIBERALIZING TRADE AND INVESTMENT IN SERVICES.

8448C Harrison, Glenn, W. and E.E. Rutstrom. THE EFFECT of MANUFACTURING SECTOR PROTECTION ON ASEAN AND AUSTRALIA:

A GENERAL EṆUILIBRIUM ANALYSIS. 
8501C Greenwood, Jeremy and Kent P. Kimbrough. FOREIGN EXCHANGE CONTROLS IN A BLACK MARKET ECONOMY.

8502C Horstmann, Ignat1us and James R. Markusen. UP YOUR AVERAGE COST CURVE: INEFFICIENT ENTRY AND THE NEW PROTECTIONISM.

8503C Gregory, Allan $W$. TESTING INTEREST RATE PARITY AND RATIONAL EXPECTATIONS TOR CANADA AND THE UNITED STATES.

8504C Kuhn, Peter and Ian Hooton. INTERNATIONAL FACTOR MOVEMENTS IN THE PRESENCE OF A FIXED FACTOR.

8505C Wong, Kar-y1u. GAINS FROM GOODS TRADE AND FACTOR MOBILITY.

8506C Weller, Paul and Makoto Yano. FUTURES MARKETS, REAL INCOME, AND SPOT PRICE VARIABILITY: A GENERAL EỌUILIBRIUM APPROACH.

8507C Dlewert, V.E. THE EFPECTS OF AN INNOVATION: A TRADE THEORY APPROACH.

8508C Ethier, Wilfred J. POREIGN DIRECT INVESTMENT AND THE MULTINATIONAL FIRM.

8509C Dinopoulos, E11as. INSIDE THE BLACK BOX: (IN) TANGIBLE ASSETS, INTRA-INDUSTRY INVESTMENT AND TRADE.

8510C Jones, Richard, John Whalley, and Randall H1gle. REGIONAL IMPACTS OF TARIFFS IN CANADA: PRELIMINARY RESULTS FROM A SMALL DIMENSIONAL NUMERICAL GENERAL EOUILIBRIUM MODEL.

$8511 \mathrm{C}$ Wha1ley, John. HIDDEN CHALLENGES IN RECENT APPLIED GENERAL EQUUILIBRIUM EXERCISES.

9512C Smith, Bruce. SOME COLONIAL EVIDENCE ON THO THEORIES OF MONEY: MARYLAND AND THE CAROLINAS.

9513C Grossman, S.J., A. Melino, and R.J. Sh11ler. ESTIMATING THE CONTINUOUS TIME CONSUMPTION BASED ASSET PRICING MODEL.

8514C Romer, Paul R. TAX EFFECTS AND TRANSACTION COSTS FOR SHORT TERM MARKET DISCOUNT BONDS.

8515C McCallum, Bennett T. ON CONSEOUUENCES AND CRITJCISMS OF MONETARY TARGETING.

8516C Dinopoulos, Ellas and Ian Wooton. A NORTH-SOUTH MODEL OF INTERNATIONAL JUSTICE.

8517C Huffman, Gregory W. A DYNAMIC EQUILIBRIUM MODEL OF ASSET PRICES AND TRANSACTION VOLUME.

8518C Huffman, Gregory W. AN ALTERNATIVE VIEW OF OPTIMAL SEIGNIORAGE.

8519C Huffman, Gregory W. ASSET PRICING WITH HETERGENEOUS ASSETS. 
8520C Hercowitz, Zvi. THE REAL INTEREST RATE AND AGGREGATE SUPPLY.

8521C Davies, James and Michael Hoy. COMPARING INCOME DISTRIBUTIONS UNDER AVERSION TO DOWNSIDE INEQUALITY.

8522C Nguyen, Trien $\mathrm{T}$. and John Whalley. COEXISTENCE OF EQUILIBRIA ON BLACK AND WHITE MARKETS.

8523C Clarete, Ramon and John Whalley. INTERACTIONS BETWEEN TRADE POLICIES AND DOMESTIC DISTORTIONS: THE PHILIPPINE CASE.

8524C Hamilton, Bob, Sharif Mohammad, and John Whalley. APPLIED GENERAL EQUILIBRIUM ANALYSIS AND PERSPECTIVES ON GROWTH PERFORMANCE.

8525C Huffman, Gregory $W$. THE LAGGED EFFECTS OF POLICY ON THE PRICE LEVEL.

8526C Laidler, David. FISCAL DEFICITS AND INTERNATIONAL MONETARY INSTITUTIONS.

$8527 \mathrm{C}$ Goodfriend, Marvin. MDNETARY MYSTIQUE: SECRECY AND CENTRAL BANKING.

8528C Nguyen, Trien $T$. and. John Whalley. GENERAL EQUILIBRIUM ANALYSIS OF PRICE CONTROLS A TWO-SECTOR COMPUTATIONAL APPROACH.

$8529 \mathrm{C}$ Heckman, James $\mathrm{J}$, and $\mathrm{v}$. Joseph Hotz. AN INVESTIGATION OF THE LABOR MARKET EARNINGS OF PANAMANIAN MALES: EVALUATING SOURCES OF INEQUALITY.

$8530 \mathrm{C}$ Greenwood, Jeremy and Gregory W. Huffman. A DYNAMIC EQUILIBRIUM MODEL OF INFLATION AND UNEMPLOYMENT.

8531C Freeman, Scott. INSIDE MONEY, MONETARY CONTRACTIONS, AND WELFARE.

8532C Paderanga, Cayetano Jr. and Ian Wooton. A POSITIVE VIEW OF INFANT INDUSTRIES.

8533C St-Hilaire, France and John Whalley. A MICROCONSISTENT DATA SET FOR CANADA FOR USE IN REGIONAL GENERAL EQUILIBRIUM POLICY ANALYSIS.

8534C Whalley, John. OPERATIONALIZING WALRAS: EXPERIENCE WITH RECENT APPLIED GENERAL EQUILIBRIUM TAX MODELS .

8535C Melvin, James R. THE GENERAL NON-EQUIVALENCE OF TARIFFS AND IMPORT QUOTAS. 
8601C Greenwood, Jeremy and R. Preston McAfee. EXTERNALITIES AND ASYMRETRIC INFORMATION.

8602C Dinopoulos, Elias and Mordecha1 E. Krelnin. IMPORT QUOTAS AND VERS: A COMPARATIVE ANALYSIS IN A THREE-COUNTRY FRAMEWORK.

8603C Clarete, Ramon and John Whalley. COMPARING THE MARGINAL WELFARE COSTS OF COMMODITY AND TRADE TAXES.

8604C Wigle, Randy. CANADIAN TRADE LIBERALIZATION: SCALE ECONOMIES IN A GLOBAL CONTEXT.

8605C Parkin, Michael. DOMESTIC MONETARY INSTITUTIONS AND FISCAL DEFICITS.

8606C Dinopoulos, Elias and Ian Wooton. INTERNATIONAL TRADE AND THE ACQUISITION OF SKILLS.

8607C Kawasak1, Selichi and John McMillan. THE DESIGN OF CONTRACTS: EVIDENCE FROM JAPANESE SUBCONTRACTING.

8608C Williamson, Stephen D. LIQUIDITY, BANKING, AND BANK FAILURES.

8609C Grossman, Gene M. and Carl Shapiro. COUNTERFEIT-PRODUCT TRADE.

8610C Deardorff, Alan V. WHY DO GOVERNMENTS PREFER NONTARIFF BARRIERS?

8611C Horstmann, Ignatlus and James R. Markusen. LICENSING VERSUS DIRECT INVESTMENT: A MODEL OF INTERNALIZATION BY THE MULTINATIONAL ENTERPRISE.

8612C Thursby, Jerry G. and Marie C. Thursby. BILATERAL TRADE FLOWS, THE LINDER HYPOTHESIS, AND EXCHANGE RISK.

8613C Clarete, Ramon and John Wha1ley. EQUILIBRIUM IN THE PRESENCE OF FOREIGN EXCHANGE PREMIA.

8614C Wooton, Ian. TOWARDS A COMMON MARKET: FACTOR MOBILITY IN A CUSTOMS UNION. 